\title{
Magnetic Susceptibility as a Tool for Investigating Igneous Rocks-Experience from IODP Expedition 304
}

by Roger C. Searle

\section{Introduction}

Continuous measurements of magnetic susceptibility have been commonly used on Ocean Drilling Program (ODP) and Integrated Ocean Drilling Program (IODP) expeditions to study minor lithological variations (for example, those related to climatic cycles) in sedimentary rocks, but they have been less frequently used on igneous rocks, although important post-cruise studies have utilized them (e.g., Ildefonse and Pezard, 2001). Here I report its use (and that of the closely related electrical conductivity) on IODP Expedition 304 to examine igneous crustal rocks. Expedition 304/305 targeted the Atlantis Massif, an oceanic core complex on the Mid-Atlantic Ridge, and recovered a suite of igneous rocks comprising mainly gabbros, troctolites, and some diabases (Blackman et al., 2006; Ildefonse et al., 2006, 2007; IODP Expeditions 304 and 305 Scientists, 2005). Shipboard measurements (on D/V JOIDES Resolution) of physical properties were made to characterize lithological units and alteration products, to correlate cored material with down-hole logging data, and to interpret broader-scale geophysical data.

\section{Shipboard Measurements}

Magnetic susceptibility, $\mathrm{k}$, is a dimensionless measure of the degree to which material can be magnetized in an external magnetic field:

$$
\mathrm{k}=\mathrm{M} / \mathrm{H}
$$

where $\mathrm{M}$ is the magnetization induced in the material by an external field of strength $\mathrm{H}$. Magnetic susceptibility is sensitive to variations in the type and concentration of magnetic grains in rocks and is thus an indicator of composi-

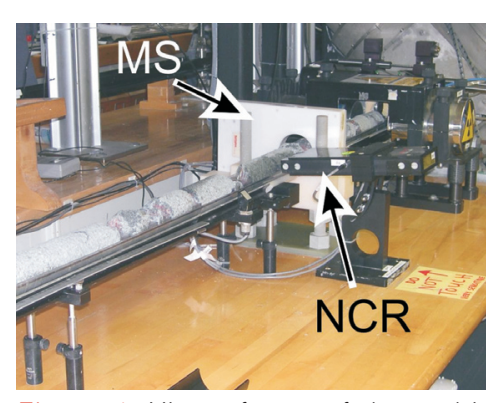

Figure 1. View of part of the multisensor track on JOIDES Resolution during Expedition 304, showing the MS and NCR sensors. tional variations.

After recovery, cores were allowed to come to approximately room temperature $\left(22^{\circ}-25^{\circ} \mathrm{C}\right)$, then magnetic susceptibility (MS) and non-contacting electrical resistivity (NCR) were measured following standard IODP procedu- res on whole core in split liner in the multi-sensor track (Blum, 1997, Fig. 1).

MS was measured inductively at 2-cm intervals down core, using a model MS2C Bartington susceptibility meter, which has an 8-cm loop and operates at $0.565 \mathrm{kHz}$ with a field intensity of $80 \mathrm{~A} / \mathrm{m}$ (Bartington Instruments, 1995). The instrument is constructed so that for a core of diameter 65 $\mathrm{mm}$, the recorded value is the absolute volume susceptibility. The diameter of the Expedition 304 cores was always smaller $(\sim 5.5-6.0 \mathrm{~cm})$, so I report results in Instrument Units (IU), which under the conditions given above approximate to dimensionless Système International (SI) units $\times 10^{-5}$. Because measured susceptibility depends on sample volume, measurements on pieces shorter than $\sim 8 \mathrm{~cm}$ will be underestimated; such samples were flagged in my interpretations. A further complication is that the Bartington MS2C sensor currently has a maximum range of $10^{4} \mathrm{IU}$; all readings greater than this lose the most significant digit, so that the signal appears to fall discontinuously to a low value, or "wrap around”. As a result, intervals where $\mathrm{k}$ values appear to approach $104 \mathrm{IU}$ and then fall rapidly should be examined and used with care. However, there is a potential solution to this as described below.

NCR was measured every $2 \mathrm{~cm}$ down core using a noncontacting inductive instrument, purpose-built for the MST by Geotek Limited (http://www.geotek.co.uk/site/index. php). Instrument output (in volts) is approximately inversely proportional to resistivity; the precise relationship was determined at the start of Expedition 304 by measuring brine samples of known salinity, though data in the IODP database are in uncalibrated voltages. The instrument is rated to

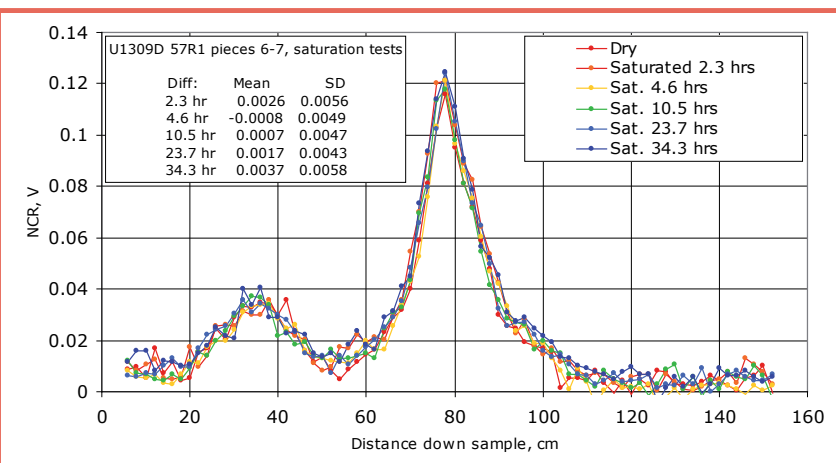

Figure 2. Results of repeated measurements of NCR on U1309D 57R-1 pieces 6 and 7, following drying and then saturation with seawater for periods from $2.3 \mathrm{~h}$ to $34.3 \mathrm{~h}$. 
measure resistivity in the range 0.1 to 10 ohm-meters. I obtained apparently useful measurements to $>100 \mathrm{ohm}-\mathrm{m}$, but these high values are poorly calibrated. It is often more useful and intuitive to consider the reciprocal of resistivity, which is conductivity, measured in siemen per meter $\left(\mathrm{S} \mathrm{m}^{-1}\right)$, and values are presented as such here. Geotek estimates the spatial resolution of the NCR as approximately $2 \mathrm{~cm}$ down core (http://www.geotek.co.uk/site/scripts/module.php? webSubSectionID=31). My calibration showed, however, that the sensor has to be between $4 \mathrm{~cm}$ and $8 \mathrm{~cm}$ from the end of the sample before the full resistivity was measured. Thus, resistivity measured on pieces shorter than $\sim 10 \mathrm{~cm}$ will be overestimated, and, as with MS, these were flagged.

\section{The Origin of Conductivity and Susceptibility in Igneous Rocks}

Electrical conductivity in rocks occurs by one of two mechanisms: ionic conductivity (in which the drift of ions through conducting pore-water carries the current) and electronic conductivity (in which electrons travel through conducting solid minerals). Most Expedition 304 rocks have low porosity $(<3 \%)$, but the connectivity of pore spaces is critical in determining ionic conductivity. Normally, resistivity was measured on the MST about $2 \mathrm{~h}$ after the core came on board (the delay being the time required for core curation), and in this time the core can lose a significant proportion of its pore water. I ran a test on two long pieces (U1309D-57R-1 Pieces 6 and 7) from Hole 1309D Unit 137 (olivine-bearing gabbro), which was very conductive. After storage on board for several days allowed them to dry out, the working and archive halves were put together and held in place by elastic bands, and then were measured dry and after saturation in seawater for periods from $2.3 \mathrm{~h}$ to $34.3 \mathrm{~h}$. Little

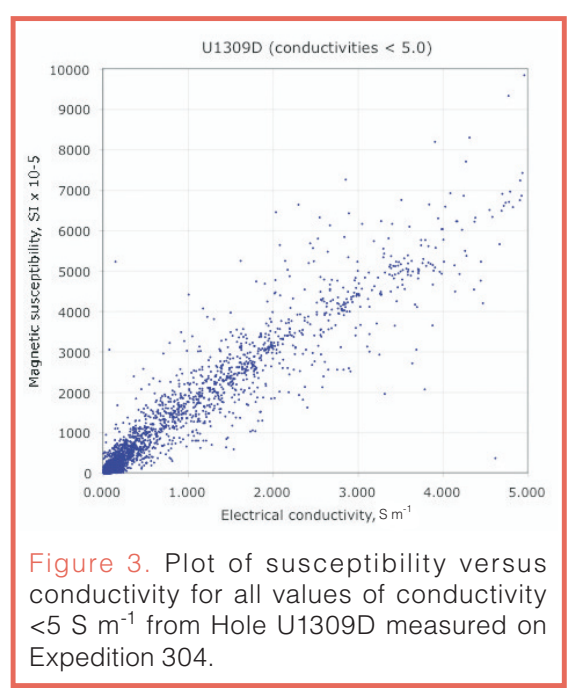

variation was seen, suggesting that ionic conductivity was not the dominant mechanism (Fig. 2). Similar results were obtained from several other sections with varying lithology.

\section{Early in \\ Expedition 304} electrical conductivity and magnetic susceptibility seemed to be closely correlated, independent of lithology (Fig. 3). This strongly suggests that the same minerals are responsible for both the conductivity and susceptibility. A check of common minerals that exhibit high conductivity and high susceptibility produced the results shown in Table 1. Pyrrhotite, ilmenite, and magnetite all have high mean susceptibility and potentially high conductivity, and are relatively common in igneous rocks. Pyrrhotite was rare in the rocks recovered during Expedition 304, and I suspect that magnetite is the
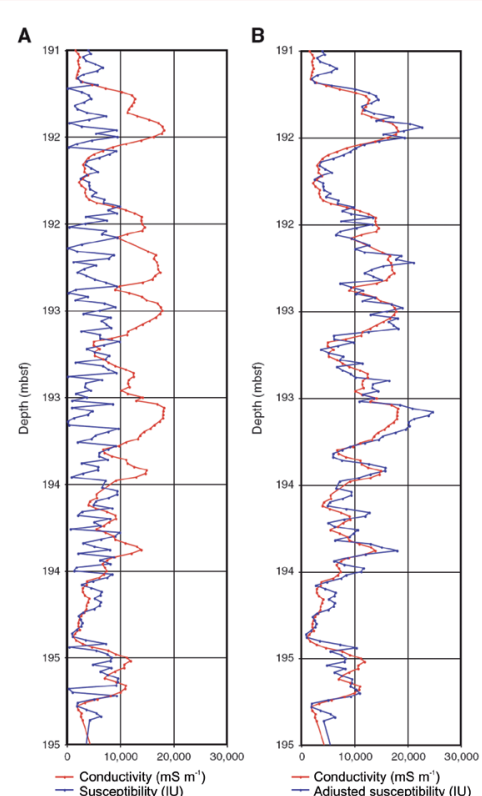

Figure 4. Plots of conductivity (red) and susceptibility (blue) against depth for sections U1309D 35R-1 to 36R-1 (unit 88, oxide gabbros). [A], logged values; [B] susceptibility augmented by integral amounts (1 or 2) of 10,000 IU to compensate for limited range of the installed susceptibility sensor. Note the good correlation with conductivity following this correction. dominant mineral, as either a primary component or one produced during serpentinization.

The strong correlation of conductivity and susceptibility offers a way of checking and perhaps correcting the wraparound of strong susceptibility signals. Figure 4a shows measured susceptibility plotted alongside conductivity for sections U1309D 35R-1 to 36R-1 (unit 88, oxide gabbros). Some parts, particularly between 194 and 195 mbsf, correlate very well, while others do not. However, by adding $10,000 \mathrm{IU}$, or occasionally $20,000 \mathrm{IU}$, to the logged value, a much improved correlation is seen (Fig. 4b). While this manual correction can be applied in some places, it is tedious, and the number of wrap-around can be ambiguous; clearly, there is need for a susceptibility meter with extended range. Results here suggest it should be increased to at least $30,000 \mathrm{IU}$ and probably to $50,000 \mathrm{IU}$.

\section{Applications}

During Expedition 304, MS sometimes showed variations that are not immediately apparent in on-board lithological

Table 1. Common minerals with high electrical conductivity or magnetic susceptibility (Telford et al., 1990)

\begin{tabular}{|l|c|c|c|c|}
\hline Mineral & Susceptibility mean, IU & Susceptibility range, IU & Conductivity mean, Sm $^{-1}$ & Conductivity range, Sm $^{-1}$ \\
\hline Pyrrhotite & 1.5 & $0.006-1.6$ & 104 \\
\hline IImenite & 1.9 & $0.3-3.8$ & $20.0-1.5 \times 10^{5}$ \\
\hline Magnetite & 6.3 & $5.0 \times 10^{-6}-5.7 \times 10^{3}$ & $20.0 \times 10^{-2}-1.0 \times 10^{3}$ \\
\hline Pyrite & 0.0015 & & $3.3 \times 10^{-4}-2.0 \times 10^{5}$ \\
\hline
\end{tabular}


descriptions. For example, Figure 5 shows the susceptibility logged for U1309B Unit 62, which appears to be a fairly uniform oxide diabase (Blackman, 2006), but it exhibits variations from essentially zero to over 5,000 IU (approximately $0.05 \mathrm{SI}$ ) over distances of $\sim 1 \mathrm{~m}$. This observation spawned the hypothesis that the variations might be related to flow phenomena and perhaps grain size variations at the edges of the unit. On-board examination of photomicrographs suggested that the intervals with low susceptibility might be places where magnetite had been extensively altered to lower susceptibility ilmenite (R. Frost, pers. comm., 2004, 2007), and led to a program of post-cruise research, which has shown that the susceptibility actually correlates quite well with observed proportion of oxides in thin section.

Following this early success in using MS to identify potential lithological variations, we instituted the practice of routinely including MS in the visual core description sheets (so-called "barrel plots") produced on board (Fig. 6). These have already proved valuable for re-surveying the Expedition 304/305 cores post-cruise (B. John, pers. comm., 2007), and for investigations of the formation mechanism of serpentine from olivine-rich troctolites (R. Frost, pers. comm., 2007).

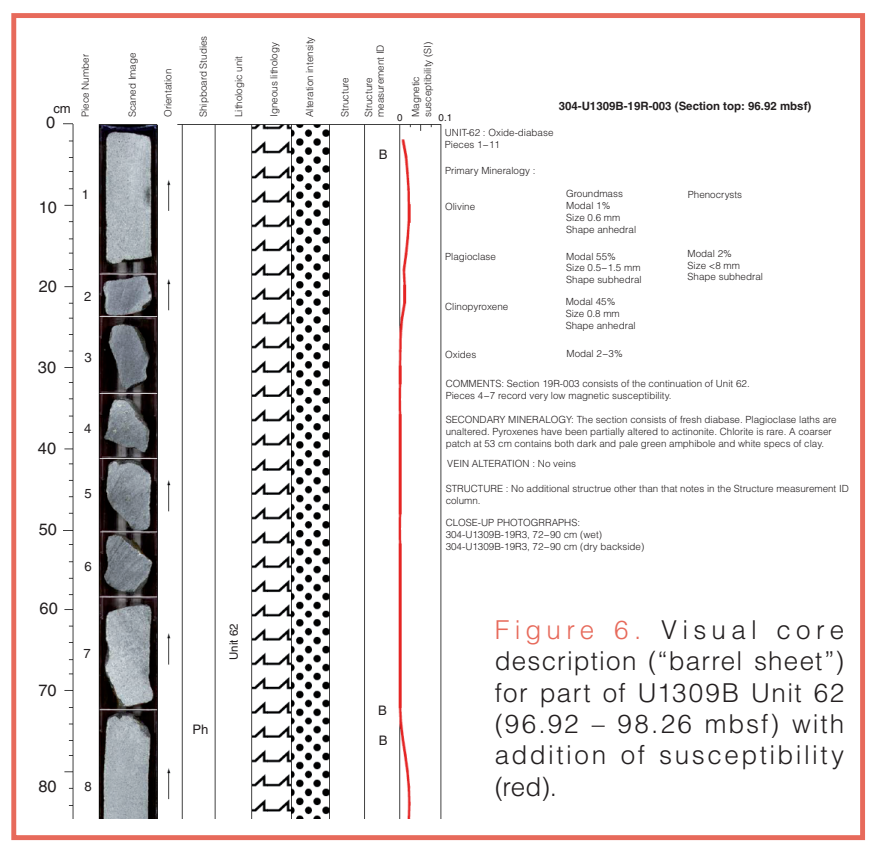

\section{Acknowledgements}

I am indebted to the help of the Expedition 304/305 shipboard scientists, ship's crews, and coring staff. Special thanks go to Physical Properties Marine Laboratory Specialist for Expedition 304, Heather Paul, who expertly guided this neophyte through the complexities of the on-board Physical Properties Laboratory. My participation in Expedition 304 was funded by the Natural Environment Research Council's thematic programme UKIODP.

\section{References}

Bartington Instruments, 1995. Operation Manual for MS2 Magnetic Susceptibility System, Oxford, U.K.

Blackman, D.K., Ildefonse, B., John, B.E., Ohara, Y., Miller, D.J., MacLeod, C.J., and Expedition 304/305 Scientists, 2006. Oceanic Core Complex Formation, Atlantis Massif: Expeditions 304 and 305 of the riserless drilling platform from and to Ponta Delgada, Azores (Portugal), Sites U1309U1311, 17 November 2004-7 January 2005, and from and to Ponta Delgada, Azores (Portugal), Site U1309, 7 January-2 March 2005. Proc. IODP, 304/305, doi:10.2204/iodp. proc.304305.2006.

Blum, P., 1997. Physical properties handbook: A guide to the shipboard measurement of physical properties of deep-sea cores. ODP Tech. Note, 26, doi:10.2973/odp.tn.26.1997.

Ildefonse, B., and Pezard, P. A., 2001. Electrical properties of slowspreading ridge gabbros from ODP Site 735, Southwest. Indian Ridge. Tectonophysics, 330:69-92, doi:10.1016/ S0040-1951(00)00220-1.

Ildefonse, B., Blackman, D., John, B.E., Ohara, Y., Miller, D.J., MacLeod, C.J., and IODP Expeditions 304/305 Scientists, 2006. IODP Expeditions $304 \& 305$ characterize the lithology, structure, and alteration of an oceanic core complex. Sci. Drill., 3:4-11.

Ildefonse, B., Blackman, D., John, B.E., Ohara, Y., Miller, D.J., MacLeod, C.J., and IODP Expeditions 304/305 Science Party, 2007. Oceanic core complexes and crustal accretion at slow-spreading ridges. Geology, 35(7):623-626, doi: 10.1130/G23531A.1.

IODP Expeditions 304 and 305 Scientists, 2005. IODP Expeditions 304 and 305: Oceanic Core Complex Formation, Atlantis Massif. Sci. Drill., 1(1):28-31, doi:10.2204/iodp. sd.1.05.2005.

Telford, W.M., Geldart, L.P., and Sheriff, R.E., 1990. Applied Geophysics. Cambridge (Cambridge University Press).

\section{Author}

Roger C. Searle, Department of Earth Sciences, Durham University, Durham, DH1 3LE, U.K., e-mail: r.c.searle@durham.ac.uk.

\section{Related Web Links}

http://www.geotek.co.uk/site/index.php http://www.geotek.co.uk/site/scripts/module. php?webSubSectionID $=31$ 